\title{
Relationships between site and stock quality in Pinus halepensis Mill. reforestation on semiarid landscapes in eastern Spain
}

\author{
Antonio D. DEL CAMPo ${ }^{a *}$, Rafael M. NAVARro CERRILlo ${ }^{\mathrm{b}}$, Javier HERMoso $^{\mathrm{c}}$, Antonio J. IbÁÑEZ \\ a E.T.S.I. Agrónomos, Dep. de Ingeniería Hidráulica y Medio Ambiente, Universidad Politécnica Valencia, Camí de Vera s/n, 46022 Valencia, Spain

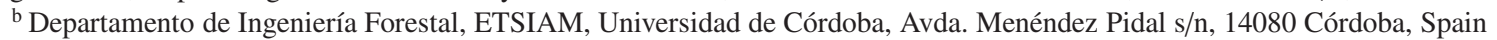 \\ ${ }^{\mathrm{c}}$ Conselleria de Territori y Habitatge, Generalitat Valenciana, c/ Gregorio Gea 27 Valencia, Spain
}

(Received 17 August 2006; accepted 6 March 2007)

\begin{abstract}
The influence of site and stock quality factors in Aleppo pine (Pinus halepensis Mill.) plantation establishment has been studied. Five stocklots with a contrasting seedling quality were planted on six different sites showing different ecologic conditions in a same regional context. This reciprocal study indicated that site factors (climate, meteorology and soil) explained most of the variability found over stock quality factors (material and performance attributes) in the overall performance results ( $F$ values for final survival were 64.2 and 14.1 for site and stocklot, respectively). There were significant interactions between both factors in survival ( $F=2.03$ for final survival) and first growth, indicating that the seedling quality attributes associated with a better performance depended on site conditions, with physiological attributes being more dependent on the site than morphological attributes. The lower the site quality (poor performance), the higher the importance of stock quality, especially that related with seedling size and macronutrient content, which showed positive correlations $(p<0.05)$ with survival, yielding differences of over $30 \%$ between stocklots. In general, a milder climate and a shallow site meant a higher mortality. The meteorology during the two years after planting confirmed this trend as survival was preferably correlated with temperature variables instead of with precipitation. In the first year, climate factors affected seedling performance more than the soil texture, whereas, in the second, growth was correlated $(p<0.01)$ with clay and silt percentages, confirming a predominant effect of site over time. Soil depth is discussed as a basic variable possessing a determinant influence on the overall results.
\end{abstract}

plantation establishment / site factors / meteorology / forest ecology / seedling physiology and morphology

Résumé - Relation entre station et qualité des plants de Pinus halepensis utilisés en reboisement dans des paysages semi-arides de l'est de l'Espagne. On a étudié l'influence de la station et de la qualité des plants dans des plantations de pin d'Alep (Pinus halepensis). Cinq lots de plants de qualité contrastée ont été plantés dans six sites différant par leurs qualités stationnelles dans un même contexte régional. Cette étude réciproque a montré que les facteurs liés à la station (climat, météorologie et sol) expliquaient la plus grande part de la variabilité des résultats obtenus (les valeurs de $F$ pour la survie définitive étaient de 64,2 et 14,1 respectivement pour la station et le lot de plant) avant la qualité des plants. Des interactions significatives on été détectées entre les deux facteurs pour ce qui concerne la survie ( $F=2,03$ pour la survie définitive) et la croissance de première année. Ce résultat montre que l'impact des critères de qualité (celui des caractères physiologiques plus que celui des caractères morphologiques) sur la survie varie en fonction de la station. La qualité des plants est d'autant plus importante que la station est peu productive, et la dimension des plants et le contenu en macronutriments révèlent des corrélations positives $(p<0,05)$ avec la survie, conduisant à des différences de plus de $30 \%$ entre les lots de plants. En général, un climat plus doux et un sol peu profond conduisaient à une plus forte mortalité. Les conditions météorologiques pendant les deux premières années après plantation ont confirmé cette tendance puisque la survie était corrélée avec les variables thermiques plutôt qu'avec les précipitations. Pendant la première année, les facteurs climatiques ont plus influencé les performances des plants que la texture du sol, alors que la deuxième année la croissance était corrélée $(p<0,05)$ avec le pourcentage d'argile et de limon confirmant l'effet prédominant de la station après la phase d'installation. La profondeur du sol a eu une influence déterminante sur l'ensemble des résultats.

installation des plantations / facteurs de site / météorologie / écologie forestière / physiologie et morphologie des plants

\section{INTRODUCTION}

The Mediterranean basin is characterized by a collection of physiographic, climatic, geological and historical land-use factors that have caused soil erosion and degradation. During the last 30 years, important and reiterated wildland fires, mainly associated with land use changes, have led to large deforested and shrubland landscapes in some areas, making the desertification hazard more acute [16]. In this sense, land restoration through reforestation has traditionally played an

* Corresponding author: ancamga@dihma.upv.es important role in these regions whenever natural regeneration has not been achieved. Aleppo pine (Pinus halepensis Mill.) has been the main species used in reforestation programmes in the Valencia region, accounting by itself for up to $31 \%$ of the total planted area and participating in mixed species reforestations in another 55\% of the total area [1]. It is one of the tree species with the most arid habitat in the area and in many situations is the only alternative for reforesting extremely harsh sites.

However, reforestation establishment success in the Mediterranean basin is dependent upon the severity of the climate. The dry, hot summers and a considerable precipitation 
irregularity during the rest of the year, combined with shallow, rocky and degraded sites, make seedling establishment difficult. These facts are some of the main reasons for the mortality rates occurring in Valencia reforestation programmes, with mean percentages of around 35\% [1]. Under these conditions, nursery cultivation and the use of a specific high quality stock is a prerequisite for reforestation success $[5,7,35]$.

During the past 10 years there has been a considerable increase in the literature concerning Aleppo pine reforestation establishment [3, 21, 23-25, 31,33]. In some of these works there is enough evidence to show that both site and stock quality factors affect outplanting results in this species. However, the magnitude of this response is highly variable due to the influence of site type on the expression of seedling quality attributes [6,17]. Thus, some improvements have been propitiated by the cited works, although the operational reforestation programmes conducted by forest administrations still lack any complementary information about what combinations of nursery cultural treatments, site preparation, planting dates or stock quality attributes are relevant in a specific site context. This situation may be due to the fact that scientific studies commonly focus on a few controllable seedling attributes, such as nutrition, morphology, water status, etc., allowing the establishment of seedling quality standards for specific experiment site conditions without any relation to other areas [14]. In this context, it is necessary to identify the major site variables that dictate responses associated with the implementation of the aforementioned reforestation techniques. No previous studies have examined either site or seedling quality factors in a reciprocal way, or their interaction, in order to establish possible variations in stock quality standards for different sites. Moreover, field performance is highly dependent on the meteorology [10] and, hence, site-climate variables may be of great use when explaining establishment variability in stock quality control programmes [15].

The aim of this research was to study the relationship between site and stock quality in the outplanting performance of Pinus halepensis Mill. In this order, the following questions were addressed: (i) What is the relative influence between stock quality and site quality on reforestation success within a particular eco-regional context? (ii) Is the relative performance of a particular stock quality consistent under different site conditions in one same eco-regional context? (iii) If not, which seedling attributes maintain a good relationship with field performance regardless of the site quality and which of them are related to specific site conditions? and, finally, (iv) Which ecological and meteorological site parameters explain reforestation success best in that eco-regional context?

\section{MATERIALS AND METHODS}

\subsection{Plant material}

A total of five seedling stocklots of Aleppo pine (Pinus halepensis Mill.), Spanish provenance Easter inland grown in the 2003 season, were used in this study (Tab. I). The stocklots were grown in five different forest nurseries and were destined for use in large-scale reforestation programmes. All stocklots belonged to one same stocktype but the nursery growing regimes differed in the application of culture variables such as growing calendar, fertilization, irrigation, growing media, and containers, resulting in different stocklot qualities (Tabs. I and II). On December 15, 2003, a random sample consisting of 200 seedlings extracted in history plots [13] from each nursery was used to determine the quality attributes for each stocklot [26] (Tab. II): Height (cm), diameter at $0.5 \mathrm{~cm}$ above the root collar (mm), twigs number, shoot and root dry weight $(\mathrm{g})$. Leaf area $\left(\mathrm{cm}^{2}\right)$ and root morphology were studied using the software WinRhizo ${ }^{\odot}$ v.3.1 (Regents Instruments Inc.), considering: total root length $(\mathrm{cm})$, root average diameter $(\mathrm{cm})$ and number of root tips. Using the colour analysis from this software, a chlorosis measurement of leaf area (\%) was also computed as defined by the proportion corresponding to the HSI colour classes of $10 ; 64 ; 158,58 ; 127 ; 168$ and $43 ; 75 ; 136$ (10\% tolerance). Pre-dawn water potential ( $\Psi, \mathrm{MPa})$ was obtained using a pressure chamber (Soil Moisture. Santa Barbara, California). A composite sample of foliar tissue from 25 plants (identical weight from every seedling) was used for macronutrient ( $\mathrm{N}, \mathrm{P}$ and $\mathrm{K}$ ) determination. The needles were oven-dried $\left(70{ }^{\circ} \mathrm{C}\right)$ and ground through a $0.5 \mathrm{~mm}$ screen. Nitrogen was determined by the micro Kjeldahl method with a Kjeltec Auto 1030 Analyser (Tecator, Sweden) after digesting the samples in concentrated $\mathrm{H}_{2} \mathrm{SO}_{4}$ with a selenium catalyst; $\mathrm{P}$ was assayed colorimetrically using the phosphomolybdovanadate method $(420 \mathrm{~nm})$ in a colorimeter (Technicon Autoanalyzer AAII); K was determined using a Varian SpectraAA-10 Atomic Absorption Spectrometer [2]. Starch and soluble sugars were determined in shoots (stem plus needles) of another 25-seedling composite sample (identical weight from every seedling) by means of a controlled acid hydrolysis procedure [29]. Root growth potential (RGP, g), performed in the greenhouse during 28 days, was estimated in 15 seedlings per stocklot. The seedlings were planted, keeping their plug, in containers filled with a perlite \#2 growing medium. Seedlings were watered but no nutrients were provided. At the conclusion of the test, the seedlings were carefully removed and their root growth determined by considering the white roots that grew outside the plug in the perlite medium. Then, the dry weight $\left(65^{\circ} \mathrm{C}, 24 \mathrm{~h}\right)$ of total new roots was recorded [27].

\subsection{Site characterization and experiment design}

The survey was carried out during the years 2004 and 2005 in six different reforestation sites evenly distributed over the forestland ranges of the Valencia province (eastern Spain), which has an extension of $10813 \mathrm{~km}^{2}$ (Tab. III). All of them are located in lands that lacked a tree cover as a consequence of wildland fires or previous agricultural uses. Typical soils in this region are xerochrepts and xerorthents with a low organic matter content, alkaline $\mathrm{pH}$ and with active calcium carbonate in the fine soil fraction. The climate is Mediterranean continental to maritime with a maximum rainfall in early autumn and a minimum one in July (Tab. III). All sites belong to the same biogeoclimatic eco-region, although to different territorial classes [8].

However, despite this general pattern, there is a considerable variation in quality between the sites due to their altitude, temperature or soil properties. Specific site conditions were characterized by a set of variables related to climate and soil, [9]: total annual, winter, spring, summer and autumn precipitations (denoted by $\mathrm{P}_{\mathrm{a}}, \mathrm{P}_{\mathrm{w}}, \mathrm{P}_{\mathrm{sp}}, \mathrm{P}_{\mathrm{sm}}$ and $\mathrm{P}_{\mathrm{f}}$ respectively, mm); annual mean temperature $\left(\mathrm{T}_{\mathrm{M}},{ }^{\circ} \mathrm{C}\right)$, mean daily maximum and mean temperatures of the warmest month (denoted by 


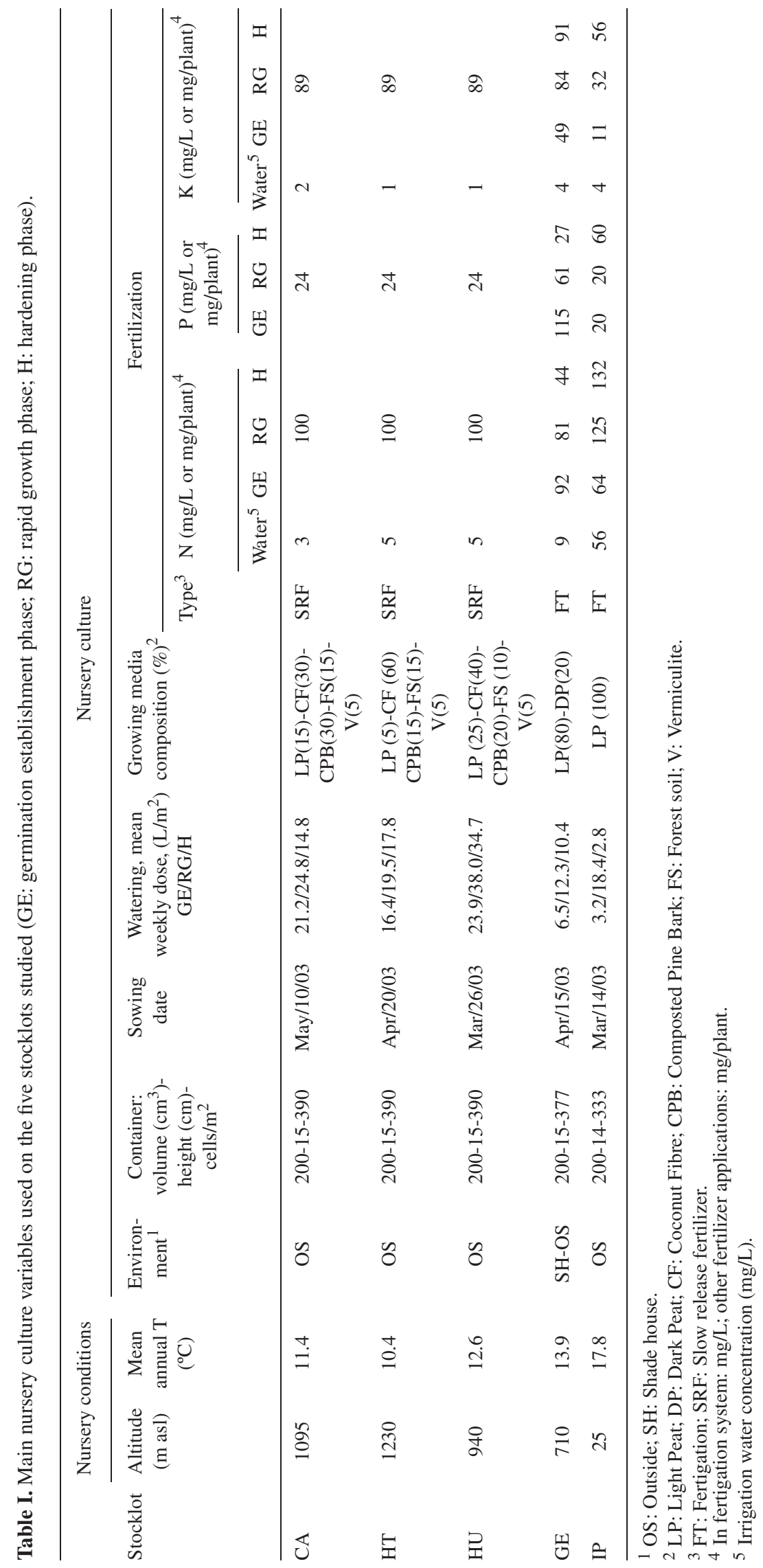


A.D. del Campo et al.

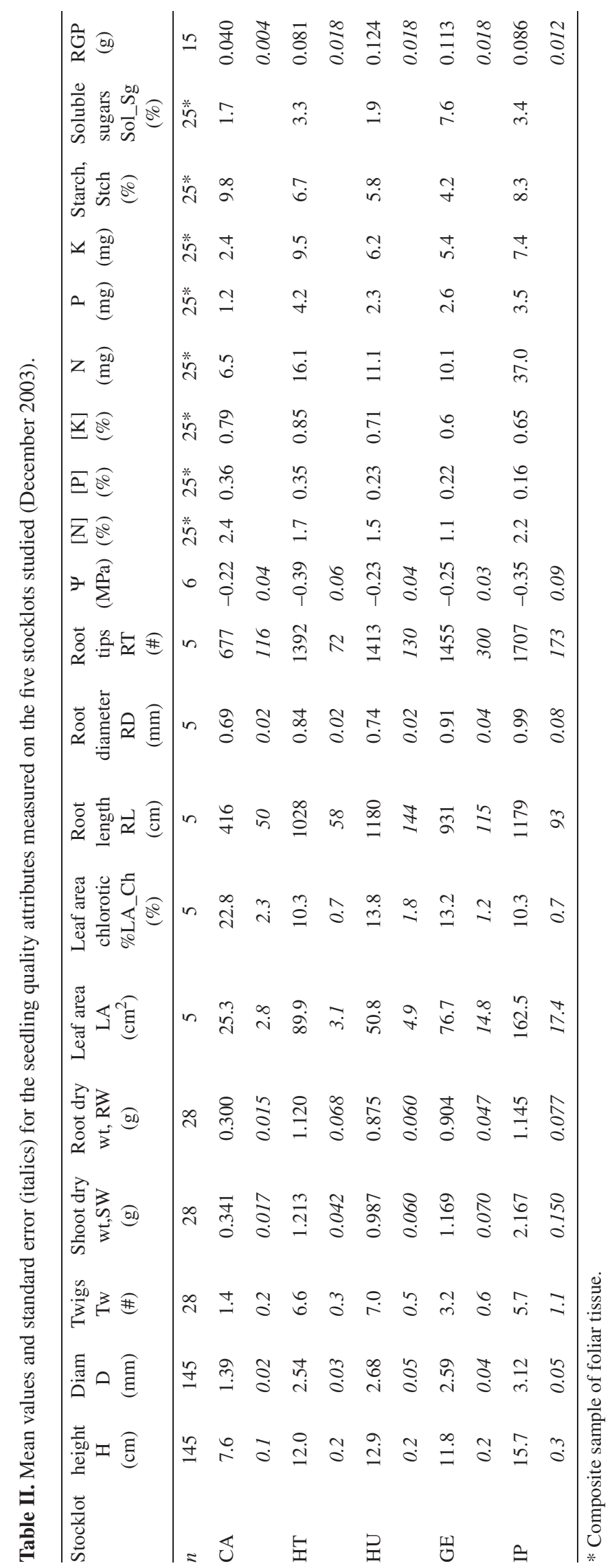




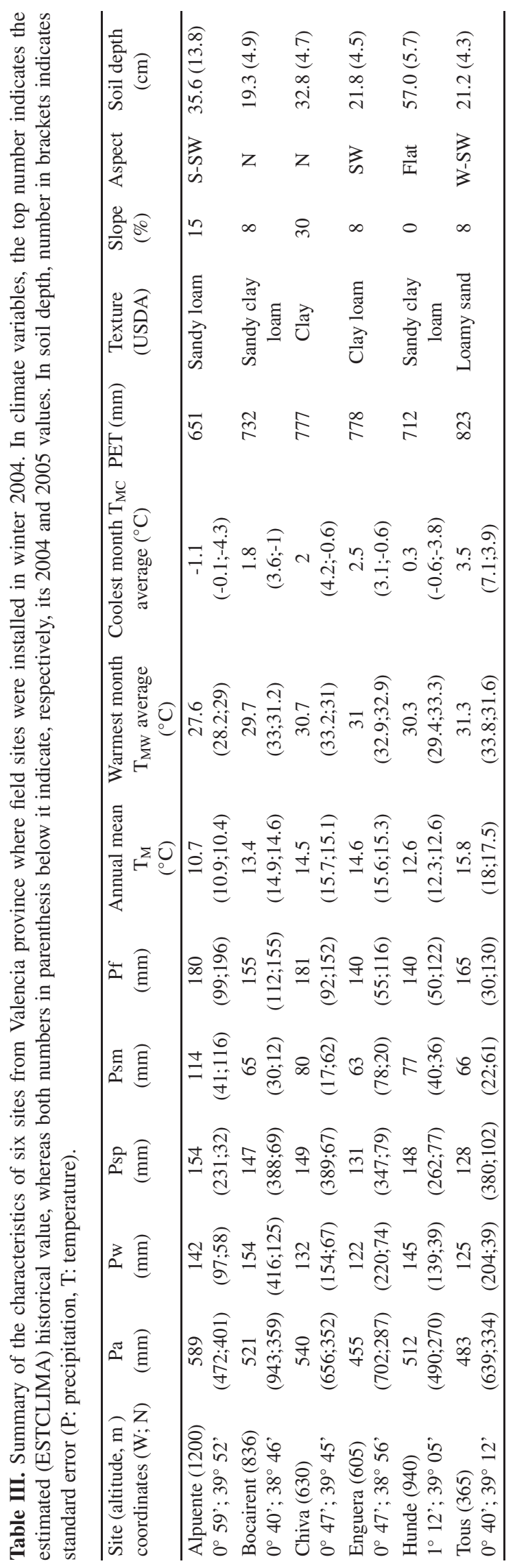


$\mathrm{T}_{\mathrm{MxW}}, \mathrm{T}_{\mathrm{MW}}$, respectively, ${ }^{\circ} \mathrm{C}$ ); mean daily minimum and mean temperatures of the coldest month (denoted by $\mathrm{T}_{\mathrm{MnC}}, \mathrm{T}_{\mathrm{MC}}$, respectively, ${ }^{\circ} \mathrm{C}$ ). These parameters were estimated for each site using the simulation model ESTCLIMA [32] by introducing their UTM coordinates. Other variables in this set are: altitude (Alt, $\mathrm{m}$ a.s.l.); thermicity index [28] defined as $I_{t}=10 \times\left(T_{M}+T_{M n C}+T_{M x C}\right), T_{M x C}$ being the average daily maximum temperature of the coldest month of the year; annual sum of the positive $\mathrm{P}_{\mathrm{i}}-\mathrm{PET}_{\mathrm{i}}$ (PET: potential evapotranspiration; $\mathrm{i}=\mathrm{Jan}, \ldots$ Dec) differences (Sup, mm); annual sum of the negative $\mathrm{P}_{\mathrm{i}}-\mathrm{PET}_{\mathrm{i}}(\mathrm{i}=\mathrm{Jan}, \ldots \mathrm{Dec})$ differences (Def, $\mathrm{mm}$ ); annual water index, defined as $\mathrm{IH}=(100 \mathrm{Sup}-60 \mathrm{Def}) / \mathrm{PET}(\mathrm{mm})$. The last three parameters are due to Thornthwaite and Mather [38]. Soil depth $\left(\mathrm{S}_{\mathrm{D}}, \mathrm{cm}\right)$ and texture through its sand, silt and clay percentages in the top soil to $25 \mathrm{~cm}$ were also measured in every site (Tab. III).

A second set of variables was related to the sites' climate during the two years after planting. These meteorological variables were: precipitation in the three weeks before planting $\left(\mathrm{P}_{3 \mathrm{WB}}, \mathrm{mm}\right)$; precipitation in the three weeks after planting $\left(\mathrm{P}_{3 \mathrm{WA}}, \mathrm{mm}\right)$; number of days from planting to the first precipitation $\geqslant 5 \mathrm{~mm}\left(\mathrm{D}_{\mathrm{P} 1}\right.$, days); total accumulated precipitation from planting to a specific date $\left(\mathrm{P}_{\mathrm{AC}}\right.$-date, $\left.\mathrm{mm}\right)$; duration of the dry period $\left(\mathrm{D}_{\mathrm{DR}}\right.$-date, days) defined for a certain time period since planting as the maximum number of consecutive days with $P<5 \mathrm{~mm}$; number of 3-week intervals without precipitation $\left(\mathrm{N}_{3 \mathrm{~W}}, \mathrm{n}\right)$, defined for a specific period since planting as the number of intervals containing at least 3 weeks without any precipitation event higher than $5 \mathrm{~mm}$; number of days with mean temperatures of between 17 and $22{ }^{\circ} \mathrm{C}\left(\mathrm{T}_{17-22}\right.$-date, days $)$ in a specific time period since planting; number of days with a minimum temperature lower than $0{ }^{\circ} \mathrm{C}\left(\mathrm{T}_{<0}\right.$-date, days) in a specific time period since planting; and number of days with a maximum temperature higher than $30{ }^{\circ} \mathrm{C}$ $\left(\mathrm{T}_{>30}\right.$-date, days) in a specific time period since planting. These periods corresponded to the seedling performance assessments, which were done in July and December in the first year (2004) and December in the second year (2005). These variables were computed from records from the weather station network located in the vicinity of the sites. Precipitation values were taken directly from these stations, whereas the temperature was corrected for altitude differences by the determination of the difference between mean monthly temperatures between the station and the site (using the ESTCLIMA model). Then, half of this difference was added to (or subtracted from) the station daily maximum and minimum temperatures, which can be considered as being a conservative criterion.

In each of the six sites, an experimental plot of about $5000 \mathrm{~m}^{2}$ was delimited for testing the effects of stocklots. The five seedling stocklots were planted following a randomized block design with 9 blocks and 10 seedlings per stocklot and block ( $n=90$ seedlings per stocklot and site). Site preparation, consisting of the removal of pre-existing natural vegetation and $30 \times 30 \times 30 \mathrm{~cm}$ hole openings and planting, was done manually by the same team in all the sites between January 15 and February 20, 2004. Field performance was assessed during 2004 (July and December) and 2005 (December) by repeated measurements of the basal stem diameter at $0.5 \mathrm{~cm}$ above the ground, total seedling height and survival on all seedlings. Growth rate was computed as the difference in height $(\mathrm{H})$ and diameter (D) between two consecutive assessments (planting to Jul-04, Jul-04 to Dec-04 and Dec-04 to Dec-05).

\subsection{Data analysis}

A two-way ANOVA design with two fixed factors $(6$ sites $\times$ 5 stocklots) was performed in order to test for main effects and in- teraction between sites and stocklots on performance. Data were examined to ensure that the variables were distributed normally and that the variances were homogeneous (Levenne test). When these conditions were not met, power functions were used to transform the variables to achieve homoschedasticity. In all statistical tests, the arcsine of the square root of survival was used as a transformation in order to compensate for variance heterogeneity. When the ANOVA indicated significant differences between treatments, the Tukey post-hoc test was selected for the comparison of multiple means. If the interaction between both factors was significant, individual post-hoc tests were made for each site. A significance level of $\alpha<0.05$ was considered in all cases. The relationships between the outplanting performance with the stocklot quality and the site variables were analyzed through a Pearson correlation coefficient [37]. When the ANOVA indicated a significant interaction between site and stocklot, then correlations were performed specifically for each site (relationships between the outplanting performance with the stocklot quality) and for each stocklot (relationships between the outplanting performance with the site) although only three stocklots were selected to be simplified.

In order to simplify the variables from site and stocklot quality and permit a better interpretation of their influence on outplanting performance, a factor analysis using the principal component analysis extraction method was performed. To minimize the number of variables with high loadings on one factor, an orthogonal rotation of factors was made through the varimax with the Kaiser Normalization method [36]. When the communality of any site or stocklot variable was lower than $80 \%$, that variable was considered individually in the correlation analysis, together with the extracted factors. In the case of site meteorological variables, the communality of most variables was low enough and the extracted factors were not considered in the correlation analyses performed. All these procedures were carried out using the SPSS version 12.0 software package (Chicago, IL, USA). In all the cases, the values presented are means $\pm \mathrm{SE}$.

\section{RESULTS}

\subsection{Meteorological conditions during the study}

Rainfall and temperature variations in 2004 and 2005 with respect to the estimated historical value are shown in Table III. Briefly, during 2004, the summer and autumn precipitation diminished considerably in most sites (below $50 \%$ of expected values), and, in 2005, the winter and spring were drier than the means (below 50\%). The annual mean temperature variation in 2004 and 2005 was small compared to historical values. The average maximum temperatures in the warmest month were slightly higher for both years. In January (coldest month), the average minimum temperatures were reasonably higher in 2004 and lower in 2005 than historical values.

\subsection{Relative influence of site and stocklot on out-planting performance}

The result of the ANOVAs performed indicated significant differences in field performance during the two years for the main effects of both site and stocklot factors, either in survival 

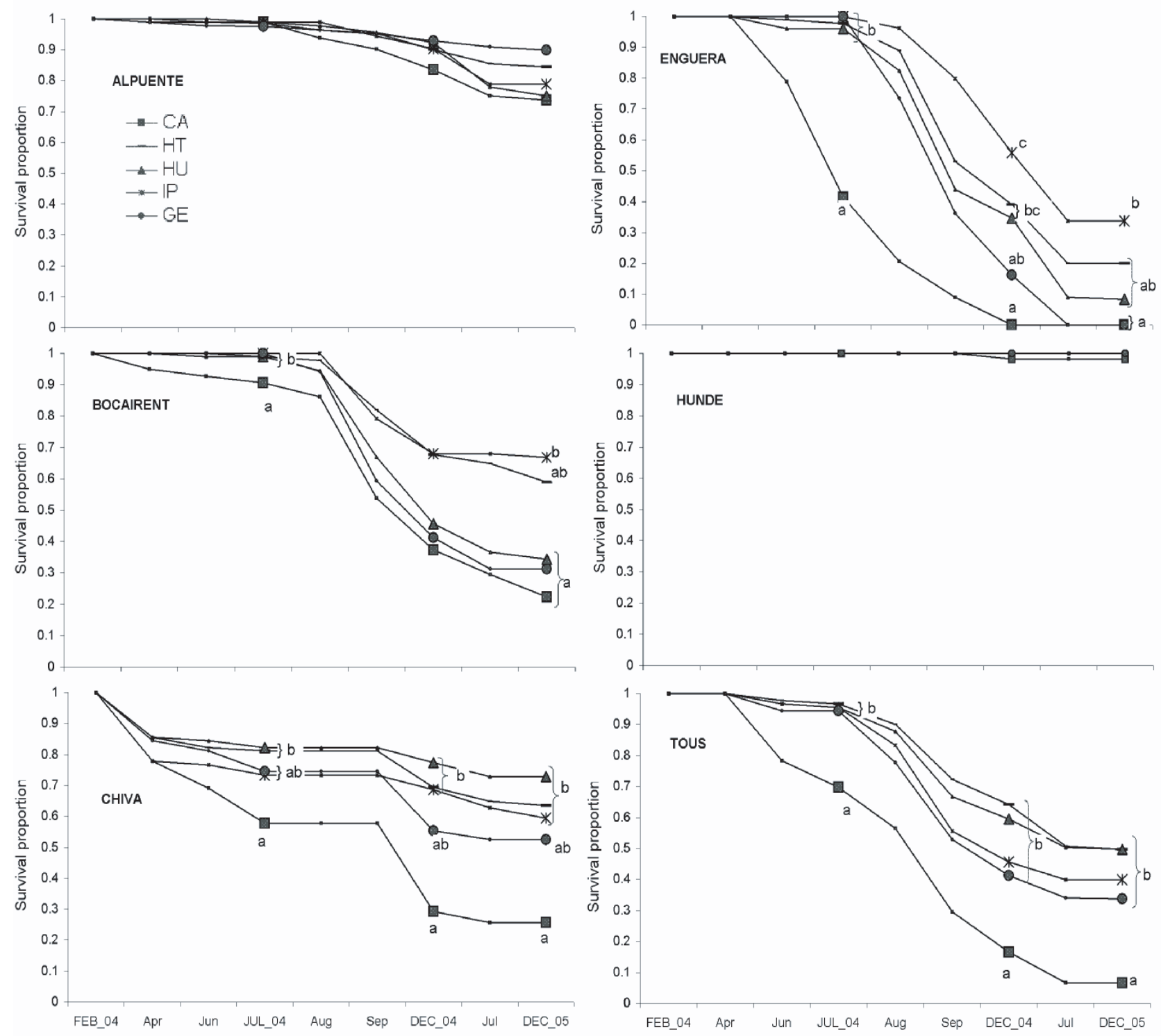

Figure 1. Field survival in five commercial stocklots of Aleppo pine during 2004-2005 in six contrasting quality sites of Valencia province (eastern Spain). ANOVAs were performed for assessments of Jul-04, Dec-04 and Dec-05; On these dates, the presence of letters indicates significance and different letters in a date-column indicate statistical differences in Tukey test at $p$-value $<0.05$.

or growth (Tab. IV and Figs. 1, 2). In addition, the interaction effect between both factors was also significant for survival performance and for the first growth period, from planting until July. However, the $F$ statistic (Tab. IV) was higher for the site factor in most of the ANOVAs carried out, keeping a higher proportion of the total variability over stocklot factor and sitexstocklot interaction. Actually, the $F$ value for the latter was comparatively low. In addition, the results indicate that the relative influence of stocklot and sitexstocklot interaction decreases with time since its $F$ value was progressively lower. However, although the site factor explained most of the result variability, the stocklot performance was examined individually for each site as the interaction factor was significant.
The order of the final mean survival in every site was Hunde $(99.6 \%)$, Alpuente $(80 \%)$, Chiva (55\%), Bocairent $(43 \%)$, Tous $(36 \%)$ and Enguera (12\%). Considering each of the six sites individually, survival and growth performance among the stocklots differed considerably in most cases (Figs. 1 and 2). The site-specific Tukey tests indicated significant differences in survival (Jul-04, Dec-04 and Dec-05) in all the sites except Alpuente and Hunde (Tab. IV and Fig. 1). On the contrary, the Enguera survival was very low for all stocklots, although there were significant differences between some of them (over 30\% after two years). The CA stocklot, which presented a lower biomass and nutrient content, exhibited a lower survival as early as the first months in all the sites (except in Hunde), and 

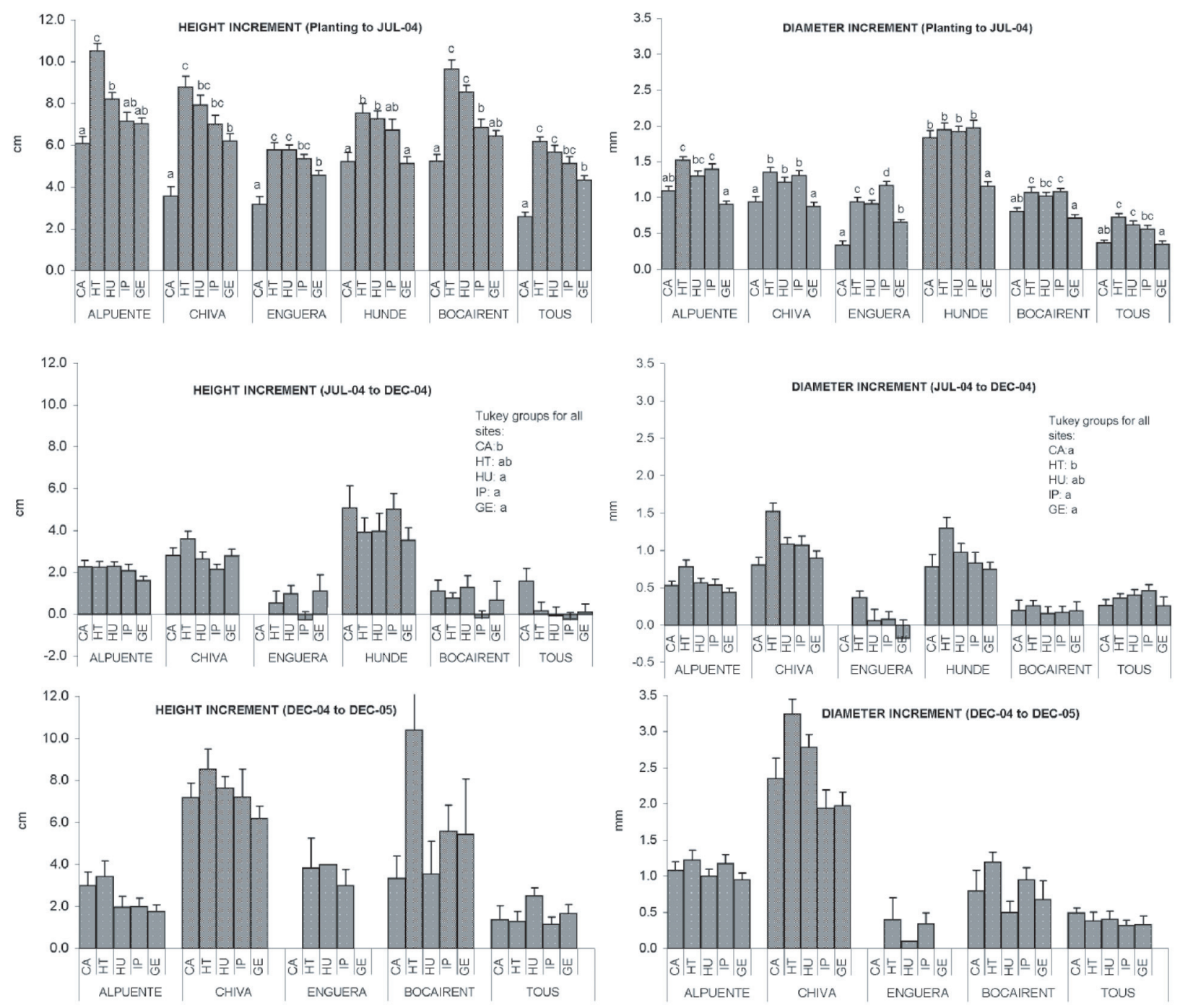

Figure 2. Height $(\mathrm{H})$ and diameter (D) increments for three time periods during 2004-2005 years in five commercial stocklots of Aleppo pine planted in six contrasting quality sites of Valencia province (eastern Spain). In the first growth period (planting to Jul-04) different letters for a site indicate statistical differences between stocklots $(p$-value $<0.05)$.

always belonged to the lowest survival Tukey group, whereas IP and HT, which presented a higher biomass and nutrient content, were grouped in the highest one (Fig. 1).

Regarding growth performance (Fig. 2), the higher growth rate for the first months after planting, common to all the stocklots and sites, followed by a sharp decrease in the summer period and a gradual recovery during the second year depending on the site, can be highlighted. During the first period, seedling growth, either in height or diameter, showed significant differences between stocklots (Tab. IV and Fig. 2), similar to that observed for survival. Thus, lower growth rates for the stocklots that had the lowest survival rates (CA and GE) can be observed, whereas HT, IP and HU showed higher growth rates. Although the interaction between site and stocklot was significant in this period, the order of the stocklots is quite similar between sites (Fig. 2, top). Actually, in the second growth period
(Jul-04 to Dec-04) there was no interaction between the site and the stocklots, the latter being classified according to their general performance throughout the sites (Fig. 2, middle). In the third period, there was no significance in growth between stocklots, this only being dependent on the site (Fig. 2, bottom).

\subsection{Outplanting performance and seedling quality attributes}

The factor analysis for seedling quality attributes (not shown) was made to extract only two factors (or components) for ease of plotting (Fig. 3A). The results explained $80 \%$ of the total variance (53.5 and $26.5 \%$ for components A1 and $\mathrm{A} 2$, respectively) and the communality (proportion of variance 
Table IV. Summary of the results ( $F$ - values and significance) of the analysis of variance (two-way ANOVA) of main effects (Stocklot and Site) and interactions on survival and growth performance of Aleppo pine during the first (Jul-04 and Dec-04) and the second (Dec-05) years since planting.

\begin{tabular}{|c|c|c|c|c|c|c|c|c|c|}
\hline & \multicolumn{3}{|c|}{ Survival } & \multicolumn{6}{|c|}{ Growth (height -H- and diameter -D- increments) } \\
\hline & Jul-04 & Dec-04 & Dec-05 & $\Delta \mathrm{H}-\mathrm{Jul04}$ & $\Delta \mathrm{D}-\mathrm{Jul04}$ & $\Delta \mathrm{H}-\mathrm{Dec} 04$ & $\Delta \mathrm{D}-\mathrm{Dec} 04$ & $\Delta \mathrm{H}-\mathrm{Dec} 05$ & $\Delta \mathrm{D}-\mathrm{Dec} 05$ \\
\hline Site & $40.28 * *$ & $50.37 * *$ & $64.22 * *$ & $64.52 * *$ & $211.39 * *$ & $43.12 * *$ & $49.50 * *$ & $33.82 * *$ & $67.60 * *$ \\
\hline Stocklot & $38.70 * *$ & $18.96 * *$ & $14.13 * *$ & $87.63 * *$ & $75.82 * *$ & $2.68 *$ & $7.21 * *$ & 2.18 & 2.00 \\
\hline Stocklot $\times$ Site & $6.50 * *$ & $1.71^{*}$ & $2.03 * *$ & $2.66^{* *}$ & $3.81 * *$ & 1.23 & 1.14 & 1.69 & 1.90 \\
\hline
\end{tabular}

$* p<0.05 ; * * p<0.01$.
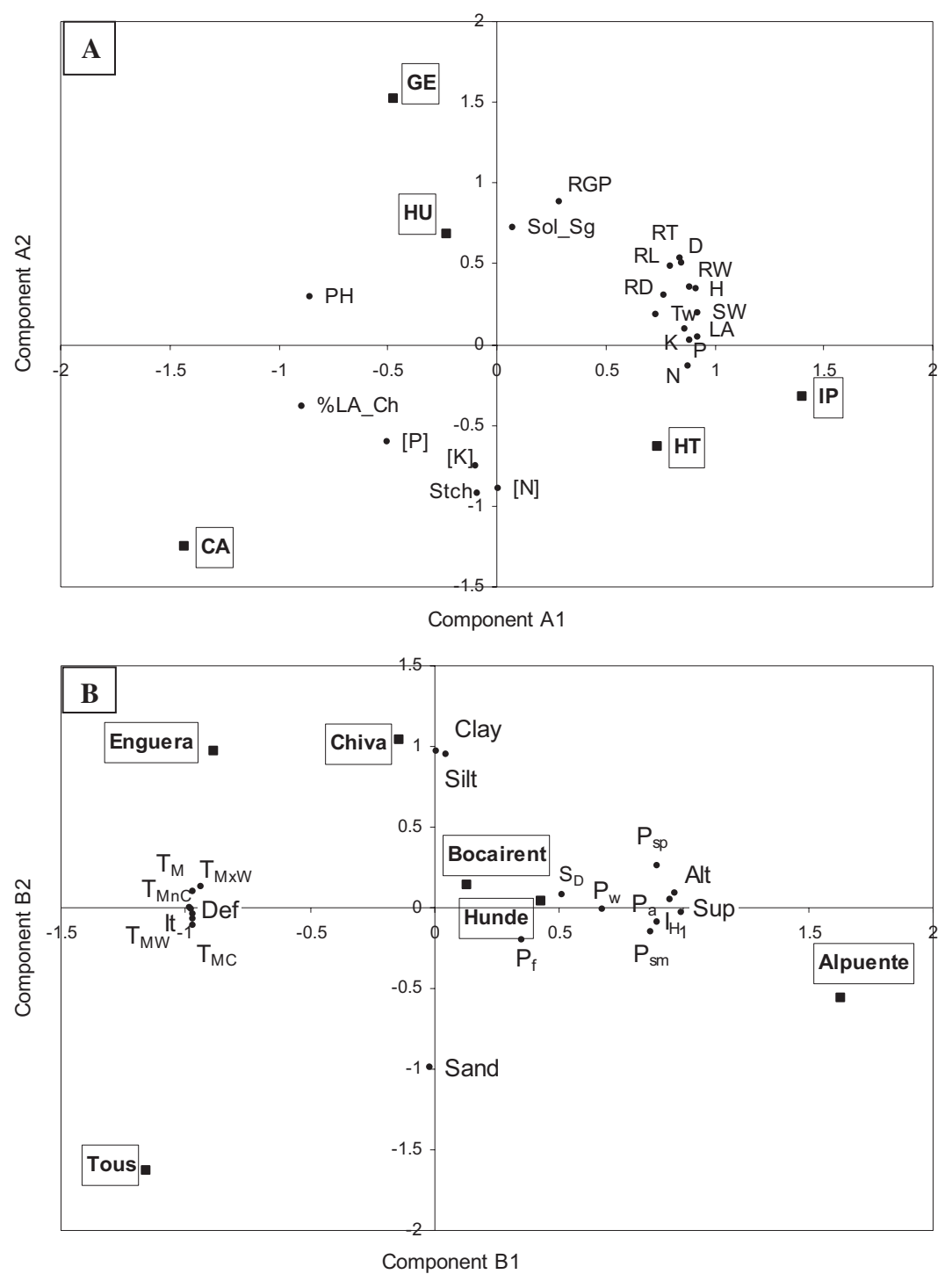

Figure 3. Plotting of the two components extracted from factor analysis representing the scoring on them for different seedling quality attributes and stocklots (A) and different climate and soil variables and sites (B). The extraction method was the Principal Component. Abbreviations are explained in the text and in Table II. 
Table V. Significant Pearson correlations of field performance (survival and growth in Jul-04, Dec-04 and Dec-05) with quality attributes in five Aleppo pine stocklots $(n=5)$ and with site variables in six different sites $(n=6)$. In the quality sub-matrix, only sites where stocklot performance was significantly different are referred (B: Bocairent; C: Chiva; E: Enguera; T: Tous). In the site sub-matrix only three stocklots $(\mathrm{Ca}, \mathrm{Ht}$ and $\mathrm{Ip})$ covering the performance rank are referred. The site or stocklot code indicates a correlation at the 0.05 level; $*$ indicates a correlation at the 0.01 level; - indicates a negative correlation. In all cases, only significant correlations are shown.

\begin{tabular}{|c|c|c|c|c|c|c|c|c|c|}
\hline & \multicolumn{3}{|c|}{ Survival } & \multicolumn{5}{|c|}{ Growth (height $-\mathrm{H}$ - and diameter -D- increments) } & \multirow[b]{2}{*}{$\Delta \mathrm{D}-\mathrm{Dec} 05$} \\
\hline & Jul-04 & Dec-04 & Dec-05 & $\Delta \mathrm{H}-\mathrm{Ju}$ ul04 & $\Delta \mathrm{D}-\mathrm{Jul04}$ & $\Delta \mathrm{H}-\mathrm{Dec} 04$ & $\Delta \mathrm{D}-\mathrm{Dec} 04$ & $\Delta \mathrm{H}-\mathrm{Dec} 05$ & \\
\hline \multicolumn{10}{|l|}{$\overline{\text { Seedling Quality }}$} \\
\hline Twigs & $\mathrm{C}, \mathrm{T}$ & $\mathrm{C}^{*}, \mathrm{~T}$ & $\mathrm{C}^{*}, \mathrm{~T}$ & & $\mathrm{~T}-$ & & & & \\
\hline $\mathrm{N}$ content & & & $\mathrm{B}, \mathrm{E}$ & & & & & & \\
\hline P content & $\mathrm{B}$ & $\mathrm{B}$ & & & & & & & \\
\hline K content & $\mathrm{B}, \mathrm{E}, \mathrm{T}$ & $\mathrm{B}, \mathrm{T}$ & & & & & & & \\
\hline COMPONENT A1 & & $\mathrm{B}, \mathrm{E}^{*}$ & $\mathrm{~B}^{*}, \mathrm{E}$ & & & & & & $\mathrm{E}^{*}-$ \\
\hline COMPONENT A2 & & & & & & & & B & \\
\hline \multicolumn{10}{|l|}{ Climate and soil } \\
\hline Winter P & $\mathrm{Ca}$ & & & $\mathrm{Ca}, \mathrm{Ht}$ & & & & & \\
\hline Soil Depth & & $\mathrm{Ca}, \mathrm{Ht}, \mathrm{Ip}$ & $\mathrm{Ca}, \mathrm{Ht}, \mathrm{Ip}$ & & $\mathrm{Ca}^{*}, \mathrm{Ht}^{*}, \mathrm{Ip}$ & $\mathrm{Ca}^{*}, \mathrm{Ht}, \mathrm{Ip}$ & & & All* \\
\hline COMPONENT B1 & & Ca,Ip & & $\mathrm{Ca}^{*}, \mathrm{Ip}$ & & & & & \\
\hline COMPONENT B2 & & & & & & & & All $*$ & All* \\
\hline \multicolumn{10}{|l|}{ Site weather } \\
\hline $\mathrm{D}_{\mathrm{DR}}-\mathrm{Jul04}$ & & & & & & & $\mathrm{Ca}, \mathrm{Ht}^{*}, \mathrm{Ip}^{*}$ & All & All $*$ \\
\hline $\mathrm{N}_{3 \mathrm{~W}}-\mathrm{Dec} 04$ & & & $\mathrm{Ca}$ & & $\mathrm{Ca}, \mathrm{Ht}, \mathrm{Ip}$ & $\mathrm{Ca}, \mathrm{Ht}^{*}, \mathrm{Ip}^{*}$ & $\mathrm{Ca}$ & & All $*$ \\
\hline $\mathrm{P}_{3 \mathrm{WA}}$ & & Ip- & & Ht- & Ip- & Ht- & & All*- & All*- \\
\hline Days to $1^{s t} \mathrm{P}$ & & $\mathrm{Ca}, \mathrm{Ht}$, & $\mathrm{Ca}, \mathrm{Ht}, \mathrm{Ip}$ & & $\mathrm{Ca}^{*}, \mathrm{Ht}$ & $\mathrm{Ca}^{*}, \mathrm{Ht}, \mathrm{Ip}$ & $\mathrm{Ca}, \mathrm{Ht}, \mathrm{Ip}$ & & All* \\
\hline $\mathrm{P}_{\mathrm{AC}}-\mathrm{Dec} 04$ & & $\mathrm{Ca}-, \mathrm{Ht}^{*}$ & $\mathrm{Ca}-, \mathrm{Ht}^{*}-$,Ip- & & & & & & \\
\hline Days $\mathrm{T}_{17-22}$-Jun04 & $\mathrm{Ca}-, \mathrm{Ht}-$ & Ca-,Ip- & Ca-,Ip- & & & & & & \\
\hline Days $T_{17-22}-\operatorname{Dec} 04$ & & $\mathrm{Ca}, \mathrm{Ht}, \mathrm{Ip}$ & $\mathrm{Ca}$ & $\mathrm{Ca}$ & & & & & \\
\hline Days $\mathrm{T}_{<0}$-Jul04 & $\mathrm{Ca}$ & $\mathrm{Ca}^{*}, \mathrm{Ht}, \mathrm{Ip} *$ & $\mathrm{Ca}^{*}, \mathrm{Ht}, \mathrm{Ip}$ & $\mathrm{Ca}$ & $\mathrm{Ca}$ & & & & \\
\hline Days $\mathrm{T}_{<0}$-Dec04 & & $\mathrm{Ca}, \mathrm{Ht}, \mathrm{Ip}$ & $\mathrm{Ca}$ & $\mathrm{Ca}$ & & & & & \\
\hline Days $\mathrm{T}_{>30}$-Dec05 & & & $\mathrm{Ca}^{*}$ & & & & & & \\
\hline
\end{tabular}

explained for a particular variable) was over $80 \%$ for all variables, except for twigs number $(57 \%)$, root diameter $(68 \%)$, $\mathrm{P}, \mathrm{K}$ and soluble sugar concentrations $(61,58$ and $52 \%$, respectively) and $\mathrm{N}, \mathrm{P}$ and $\mathrm{K}$ contents $(79,78$ and $76 \%$, respectively). Figure $3 \mathrm{~A}$ shows the score of each variable on both components as well as the score of each of the five stocklots. A higher and stronger association of morphology-related variables with Component A1 and a higher and weaker association of physiological variables with Component A2 stand out.

Significant correlations between seedling quality attributes (including both components extracted) and field performance are shown individually for each site in Table V (Hunde and Alpuente sites are omitted since the post-hoc tests did not detect differences between the stocklots' performance). Positive relationships for survival with Component A1 and, for the second year, for height growth with Component A2 were obtained (Tab. V). In particular, the seedling size (associated with Component A1, Fig. 3A) was positively correlated with survival in Enguera (clay and intermediate temperature) and Bocairent (balanced texture and intermediate temperature), which means that larger seedlings survived better in some of the worst (lower survival) sites. In the sandy and warmest site of Tous and in the site of Chiva (mostly clayey soil with an intermedi- ate temperature regime) survival was also positively correlated with size (twigs number and other size attributes omitted in favour of components). Physiological attributes (mostly associated with Component A2) showed lower correlations, those standing out being those of nutrient contents, which were sitespecific (Tab. V). On the contrary, correlations with growth performance were very scarce.

\subsection{Outplanting performance and site quality variables}

Field performance and the variables selected for site characterization (climatic and edaphic) also presented significant correlations (Tab. V). To avoid an excess of information, we have only shown the results for HT, IP and CA, the three stocklots which gave contrasting performance results (although the 2005 growth was analyzed for all stocklots because of the absence of differences between them). The factor analysis for site variables (not shown) extracted two factors (Fig. 3) which explained $82 \%$ of the total variance (66 and 16\% for components B1 and B2, respectively). The communality was in the range of 78-98\% for all variables, except for $\mathrm{P}_{\mathrm{W}}(45 \%)$, $\mathrm{P}_{\mathrm{F}}(16 \%)$ and soil depth $(27 \%)$. Figure 3B shows the score of each variable on both components as well as the score of 
each of the six sites. A higher association of climate-related variables with Component B1 (temperature being negatively correlated and rainfall positively correlated) and a higher association of soil texture variables with Component B2 (sand being negatively correlated and clay and silt positively correlated) stand out (Fig. 3B). The correlation analysis for these two factors yielded positive relationships for survival and first diameter growth with Component B1 and for the second year growth with Component B2 (Tab. V). Thus, site temperature variables had a negative relationship with survival and first diameter growth, whereas clay and silt textures were only correlated with growth in the second year. In addition, a noticeable element is the site soil depth correlations with performance (survival and growth), yielded both in the first and the second year.

The factor analysis for meteorological variables was rejected because of the loss of important correlations (when only using the components) with performance variables. In the meteorological setting described before, the results indicate that survival was preferably correlated with temperature variables instead of precipitation, with the cool and temperate days favouring survival in the three stocklots (Tab. V). In this sense, the worst performing stocklot (CA) showed more correlations than the others, indicating a greater dependence on meteorology. Precipitation-related variables $\left(\mathrm{P}_{3 \mathrm{WA}}, \mathrm{N}_{3 \mathrm{~W}}\right.$-Dec, $\mathrm{P}_{\mathrm{AC}}-\mathrm{Dec}$ and $\mathrm{D}_{\mathrm{P} 1}$ ), strongly biased by rain events in Enguera and Tous at planting, showed poor and contradictory correlations with survival and growth.

\section{DISCUSSION}

Both seedling and site quality have been thoroughly proven to play an important role in plantation success $[11,14]$. Our two years of out-planting results agree with this statement, as the survival and growth varied widely between sites and stocklots, indicating a predominant effect of site over stocklot quality that increased with time within the temporal and ecoregional context considered. In addition to this, the stocklot quality expression depended on site.

Final survival rates (and growth) observed in some of the sites studied (mainly in Enguera, Tous and Bocairent) can be considered as being very low when compared to those reported in other studies with the species $[19,21,25]$ and are unacceptable for reforestation works. One of the reasons to explain the low survival recorded in our study could be the shallowness of soils and, consequently, the manual hole-opening site preparation which is common to this area. Although mechanized site preparation is not viable in many sites because of their rocky nature, its ability to improve survival and growth in the species in similar situations has been verified $[1,3]$. In fact, in our study, the performance of all stocklots was correlated with soil depth, which was, for most of the sites, the unfavourable range of around $20-30 \mathrm{~cm}[1,4,20]$. This site variable seems to have had an important influence on the overall results.

The heterogeneity previously reported for Aleppo pine commercial stock [30] was confirmed in our stocklots, which presented a wide range for most quality attributes that ultimately affected out-planting performance in the six sites tested. However, survival and growth performance was affected by stocklot quality especially in those sites with high mortality rates (the worst quality sites), lacking any influence in the best survival sites. This confirms that the influence of seedling quality on survival is proportionally higher as the site quality decreases $[5,35]$.

In Aleppo pine, the effect of seedling quality on field performance is well known [25,31] as is its greater influence when site conditions are harsher $[19,21]$. However, in spite of this consensus, there is no uniformity in the attributes that promote a successful establishment $[6,17,22]$. Morphological and physiological attributes seem to be positively correlated with survival in most studies, as in our case. However, it should be noted that our correlations were more pronounced due to the smallest size stocklot (CA), which may be below marketable specifications. Nutritional status is another debated topic regarding Aleppo pine seedling quality $[19,22,25]$. Oliet et al. [22], in a recent review, deduced only a marginal effect $(p<0.1)$ of $\mathrm{N}$ concentration on field survival. We did not find this relation but, rather, a poor performance response for the stocklot that presented the highest value in this attribute (CA: $2.4 \%$ ). On the contrary, we found correlations between $\mathrm{N}$ content and survival in some of the worst sites (Enguera and Bocairent) as well as for $\mathrm{P}$ and $\mathrm{K}$ contents, all in the poor-quality sites. Thus, potassium content would improve survival in these sites, particularly in sandy low-fertility soil (Tous), whereas phosphorus would be appropriate in a high $\mathrm{pH}$ limestone-derived soil $[24,39]$. These findings emphasize three points that would agree with other studies cited above: (i) the positive influence of nutrient and morphology on field performance in Aleppo pine; (ii) the fact that $\mathrm{N}$ improves survival in the harsher sites and (iii) that nutrient influence on performance is highly dependent on site characteristics.

Growth performance was similar to survival in the first period, whereas in the second period the differences between stocklots decreased and even CA showed a higher height growth than other stocklots like IP or HU. This may be explained by the fact that younger and smaller seedlings from woody plants experience higher relative growth rates [12]. However, it does not seem to be an establishment advantage as its mortality rates did not decrease any more than the other stocklots did (see Alpunte and Bocairent sites). During the second year, growth was probably more controlled by site properties (as observed in the results section) along with microsite characteristics, as can be deduced from the larger standard error in Figure 2.

From the aforementioned arguments, it could be assumed that seedling quality is highly necessary when the site quality is worse. So, there is a need to establish or identify which site variables would be the most useful ones for this purpose in a specific regional context. In this sense, our results indicated that different site-defining variables played different roles during the period studied. In the soil and climate group, precipitation and evapotranspiration-related variables, which are associated with better site quality indexes in the Spanish range of this species [9], were also indicative of site quality 
from a reforestation establishment point of view since they were positively correlated with Component B1, which was related to higher survival rates in some stocklots. Temperaturerelated variables (negatively correlated with Component B1) influenced post-summer establishment, meaning higher mortality when the site was warmer. Soil texture (or Component B2) showed a scant relationship with the out-planting performance, especially with survival, despite its considerable variation: sand and clay were in the range of $27-84$ and $2-44 \%$, respectively. Thus, texture influenced performance only for second year growth, with clay and silt percentages associated with higher height and diameter growth rates than in sandy soils, revealing a possible fertility influence. This result, agrees with the negative correlation between the soil sand percentage in Aleppo pine stands and its site quality index, which is calculated from the stand dominant height [9]. This fact, of growth dependence from site factors in the second year, could mean the overcoming of the establishment phase [5]. In the Valencia region, survival and growth in marl and limestone soils are related to a lower proportion of finer soil particles, according to some studies [1,40], although others [39] did not find this relationship. In fact, these results may rather be an effect of the different depths commonly associated with both soil types, a variable that has shown more correlations with performance than any other in our study.

On the other hand, meteorological variables have also played an important role in performance. The establishment weather condition is a determinant factor that affects performance $[15,19]$. In our study, mild to cool temperature regimes improved survival and first growth (in CA stocklot) in agreement with the results observed for climate. This indicates the greater importance of temperature over precipitation, which could be partially explained by the fact that the rainfall in the first months of the research was sufficiently heavy in all the sites and, hence, no discriminating effect was associated with them. This occurred especially on planting days in the sites that recorded the lowest survival rates, making some of our precipitation variables yield contradictory correlations with performance. However, the 2004 summer and autumn precipitations, which are reported to influence the survival of Aleppo pine $[19,31]$, were very low for most sites except in the lowest survival site of Enguera (see Tab. III), and no correlation was detected. This may suggest that, in our regional context, temperature would explain performance results in a better way than precipitation, although Alloza [1] reported significant relationships between the length of dry periods and survival, which we did not find. In a recent review on Mediterranean reforestation works [18], the role of other weather variables besides rainfall has been shown. Other studies [15] also obtained significant relationships in a wide regional context between survival and the number of days on which a surface temperature of $30{ }^{\circ} \mathrm{C}$ was exceeded. Moreover, correlations were higher for the lowest surviving stocklot (CA), underlining that a vulnerability to meteorology increases with poor stocklot quality.

Most of the results obtained in our study, as well as their consistency with previous work on the species, can be explained by considering soil depth as the main site variable. In stony shallow soils, seedling roots have to expend additional resources searching for bedrock cracks before warm temperatures dry out the soil profile and deplete available water in the first $30 \mathrm{~cm}$ [20]. Higher plant size and nutrient reserves allowed for a higher root gross growth and, hence, a greater potential for finding deep crevices, an ability of the species to overcome water stress (Oppenheimer, 1957, cited in [34]). Cooler temperatures (low evaporation demand), deeper soils (higher water content), heavier site preparation, early season planting, summer storms, etc. would affect this basic process and, therefore, make seedling quality relatively less important. Soil depth is one of the main limiting factors to reforestation in semiarid climates [4] and is, in our view, the first site variable that can explain performance differences in our results and those obtained for other areas with annual precipitation in the approximately $200 \mathrm{~mm}$ range but with survivals of over $80 \%$.

\section{CONCLUSION}

Results from this experiment indicate that site is the main factor explaining field performance in Aleppo pine reforestation over seedling quality factors, which may be more or less relevant according to site conditions. The best quality sites (in terms of seedling performance) were those associated with cooler temperature regimes throughout the year and deeper soils. In these cases, the seedling quality effect may be inexistent. On the contrary, shallow, warm sites had a negative influence on seedling performance despite the favourable rain events recorded on them. Here, seedling size and nutrient contents seem to favour survival, probably because they promote a higher growth of roots before the soil profile dries out. In this sense, soil depth, climate evaporation demand and root growth potential could be a good variable set to model establishment success and this deserves additional research.

Acknowledgements: This study is incorporated in the project "Improvement of reforestation establishment in the province of Valencia through the definition of seedlings quality standards" signed by the Polytechnic University of Valencia and the Valencia Regional Government (Generalitat Valenciana). The authors are grateful to VAERSA staff and Raul Díez for technical support on field planting. We would also like to thank Dr J. García-de la Cuadra and the Laboratorio Agroalimentario in Burjassot (Valencia) for their support on plant chemical analyses.

\section{REFERENCES}

[1] Alloza J.A., Análisis de repoblaciones forestales en la Comunidad Valenciana. Desarrollo de criterios y procedimientos de evaluación, Ph.D. thesis, Univ. Politécnica Valencia, Valencia, 2003.

[2] AOAC, Official methods of analysis, Association of Official Analytical Chemists, 17th ed., Washington, DC, 2000.

[3] Barbera G.G., Martinez-Fernandez F., Alvarez-Rogel J., Albaladejo J., Castillo V., Short- and intermediate-term effects of site and plant preparation techniques on reforestation of a Mediterranean semiarid ecosystem with Pinus halepensis Mill., New For. 29 (2005) 177198. 
[4] Bonfils P., Le classement des sols en vue de la reforestation en zone méditerranéenne, Rev. Forest. Fr. 30 (4) (1978) 271-282.

[5] Burdett A.N., Physiological processes in plantation establishment and the development of specifications for forest planting stock, Can. J. For. Res. 20 (1990) 415-427.

[6] Cortina J., Navarro R.M., del Campo A., Evaluación del éxito de la reintroducción de especies leñosas en ambientes Mediterráneos, in: Cortina J. et al. (Eds.), Calidad de planta forestal para la restauración en ambientes Mediterráneos. Estado actual de conocimientos, O.A.P.N. Ministerio Medio Ambiente, Madrid, 2006, pp. 11-29.

[7] Duryea M.L., Evaluating seedling quality: importance to reforestation, in: Duryea M.L. (Ed.), Proceedings: Evaluating seedling quality: principles, procedures and predictive abilities of major test, Forest Research Laboratory, Oregon State University, Corvallis, 1985, pp. 1-4.

[8] Elena Rosselló R. (Ed.), Clasificación biogeoclimática de España peninsular y balear, MAPA, Madrid, 1997.

[9] Gandullo J.M., Sánchez Palomares O., Estaciones ecológicas de los pinares españoles, MAPA, Colección Técnica ICONA, Madrid, 1994.

[10] Gomez Sanz V., Elena Roselló R., Investigación de las marras causadas por factores ecológicos de naturaleza meteorológica, Cuad. Soc. Esp. Cienc. For. 4 (1997) 13-25.

[11] Hobbs S.D., The influence of species and stocktype selection on stand establishment: an ecophysiological perspective, in: Duryea M.L., Brown G.N. (Eds.), Seedling physiology and reforestation success, Nijhoff/Junk Pub., Dordrecht, 1984, pp. 177-224.

[12] Hunt R., Cornelissen J.H.C, Components of relative growth rate and their interrelations in 59 temperate plant species, New Phytol. 135 (1997) 395-417.

[13] Landis T.D., Karrfalt R.P., Improving seed-use efficiency and seedling quality through the use of history plots, Tree Planters Notes 38 (3) (1997) 9-15.

[14] Mattsson A., Predicting field performance using seedling quality assessment, New For. 13 (1997) 227-252.

[15] McTague J.P., Tinus R.W., The effects of Seedling Quality and Forest Site Weather on Field Survival of Ponderosa Pine, Tree Planters Notes 47 (1) (1996) 16-23.

[16] Millán M.M., Estrela M.J., Sanz M.J., Mantilla E., Martín M.F., et al., Climatic feedbacks and desertification: The Mediterranean model. J. Climate, 18 (2005) 684-701.

[17] Navarro R.M., Villar-Salvador P., del Campo A., Morfología y establecimiento de los plantones, in: Cortina J. et al. (Eds.), Calidad de planta forestal para la restauración en ambientes Mediterráneos. Estado actual de conocimientos, O.A.P.N. Ministerio Medio Ambiente, Madrid, 2006, pp. 67-88.

[18] Navarro R.M., del Campo A., Cortina J., Factores que afectan al éxito de una repoblación y su relación con la calidad de la planta, in: Cortina J. et al. (Eds.), Calidad de planta forestal para la restauración en ambientes Mediterráneos. Estado actual de conocimientos, O.A.P.N. Ministerio Medio Ambiente, Madrid, 2006, pp. 31-46.

[19] Oliet J., Planelles R., Lopez M., Artero F., Efecto de la fertilización en vivero sobre la supervivencia en plantación de Pinus halepensis, Cuad. Soc. Esp. Cien. For. 4 (1997) 69-79.

[20] Oliet J., Planelles R., Lopez-Arias M., Artero F., Soil water content and water relations in planted and naturally regenerated Pinus halepensis Mill. seedlings during the first year in semiarid conditions, New For. 23 (2002) 31-44.

[21] Oliet J., Planelles R., Artero F., Martínez Montes E., Alvarez Linarejos L., Alejano R., Lopez Arias M., El potencial de crecimiento radical en planta de vivero de Pinus halepensis Mill. Influencia de la fertilización, Investig. agrar. Sist. Recur. For. 12 (2003) 51-60.

[22] Oliet J.A., Valdecantos A., Puértolas J., Trubat R., Influencia del estado nutricional y el contenido en carbohidratos en el establecimiento de las plantaciones, in: Cortina J. et al. (Eds.), Calidad de planta forestal para la restauración en ambientes Mediterráneos. Estado actual de conocimientos, O.A.P.N. Ministerio Medio Ambiente, Madrid, 2006, pp. 389-117.

[23] Pardos M., Royo A., Gil L., Pardos J., Effect of nursery location and outplanting date on field performance of Pinus halepensis and Quercus ilex seedlings, Forestry 76 (2003) 67-81.

[24] Pausas J.G., Bladé C., Valdecantos A. et al., Pines and oaks in the restoration of Mediterranean landscapes of Spain: New perspectives for an old practice - a review, Plant Ecol. 171 (2004) 209-220.

[25] Puertolas J., Gil L., Pardos J.A., Effects of nutritional status and seedling size on field performance of Pinus halepensis planted on former arable land in the Mediterranean basin, Forestry 76 (2003) $159-168$

[26] Ritchie G.A., Assessing seedling quality, in: Duryea M.L., Landis T.D. (Eds.), Forest nursery manual: production of bareroot seedlings, The Hague, Martinus Nijhoff/Dr. W. Junk publishers, OSU, Corvallis, OR, 1984, pp. 243-259.

[27] Ritchie G.A., Dunlap J.R., Root growth potential: its development and expression in forest tree seedlings, N.Z. J. For. Sci. 10 (1980) 218-248.

[28] Rivas-Martínez S., Sánchez-Mata D., Costa M., North American boreal and western temperate forest vegetation (syntaxonomical synopsis of the potential natural plant communities of North America, II), Itinera Geobotanica, 12 (1999) 3-311. http://www.globalbioclimatics.org/book/namerica2/namerica.htm.

[29] Rose R., Rose C.L., Omi S.K., Forry K.R., Durall D.M., Bigg W.L., Starch determination by perchloric acid vs. enzymes: evaluating the accuracy and precision of six colorimetric methods, J. Agric. Food Chem. 39 (1991) 2-11.

[30] Royo A., Fernández M., Gil L., González E., Puelles A., Ruano R., Pardos J., La calidad de la planta de vivero de Pinus halepensis destinada a repoblación forestal. Tres años de resultados en la Comunidad Valenciana, Montes 50 (1997) 29-39.

[31] Royo A., Gil L., Pardos J., Effect of water stress conditioning on morphology, physiology and field performance of Pinus halepensis Mill. seedlings, New For. 21 (2001) 127-140.

[32] Sánchez Palomares O., Sánchez Serrano F., Carretero Carrero M.P., Modelos y cartografía de estimaciones climáticas termopluviométricas para la España peninsular, Instituto Nacional de Investigación y Tecnología Agraria y Alimentaria, MAPA, Madrid, 1999.

[33] Saquete Ferrandiz A., Lledó Solbes M.J., Escarré Esteve A., Ripoll Morales M.A., De-Simón Navarrete E., Effects of site preparation with micro-basins on Pinus halepensis Mill. afforestations in a semiarid ombroclimate, Ann. For. Sci. 63 (2006) 15-22.

[34] Schiller G., Ecophysiology of Pinus halepensis Mill. and Pinus brutia Ten. in: Ne'eman G., Trabaud L. (Eds.), Ecology, biogeography and management of Pinus halepensis and Pinus brutia forest ecosystems in the Mediterranean basin, Backhuys Publishers, Leiden, The Netherlands, 2000, pp. 51-65.

[35] Simpson D.G., Ritchie G.A., Does RGP predict field performance? A debate, New For. 13 (1997) 253-277.

[36] SPSS Inc., SPSS for Windows, release 12.0, SPSS. Inc., Chicago, 2003.

[37] Steel R.G.D., Torrie J.H., Principles and procedures of statistics. A biometrial approach, 2nd ed., McGraw Hill, 1988.

[38] Thornthwaite C.W., Mather J.R., Instructions and tables for computing potential evapotranspiration and the water balance. Publications in Climatology 10 (3) (1957) 185-311.

[39] Valdecantos A., Cortina J., Vallejo V.R, Nutrient status and field performance of tree seedlings planted in Mediterranean degraded areas, Ann. For. Sci. 63 (2006) 249-256.

[40] Vilagrosa A., Seva J.P., Valdecantos A., Cortina J., Alloza J.A., Serrasolses I., Diego V., Abril M., Ferran A., Bellot J., Vallejo V.R., Plantaciones para la restauración forestal en la Comunidad Valenciana, in: Vallejo V.R. (Ed.), La restauración de la cubierta vegetal en la Comunidad Valenciana, CEAM, Valencia, 1997, pp. $435-546$. 